\title{
Training Health Professionals in Teaching Competences
}

\author{
Arànega Susanna, Serrat Núria \\ University of Barcelona, Barcelona, Spain
}

\begin{abstract}
This text presents the experience of training the trainers being carried out with professionals from hospitals and public health centres in the territory of Catalonia (Spain). The text describes the structure of the innovation training program, emphasizing the methodology used that represents on of the strengths of the program. The objective is to provide a vision of training in organizations from a practice that is proving successful. The results presented and emerged valuations of the managers of the training and participants provide evidence of their own pedagogical value. From the analysis of the obtained results, the paper ends with future proposals for new training programs.
\end{abstract}

Keywords: training the trainers, training in organizations, training in health

\section{Introduction}

Initial training provides graduates with the knowledge and skills they need to enter the workforce in their specialised field (Alsina, 2010), "A knowledge base which will serve as a foundation in achieving the new learning they require for carrying out their work in accordance with social change and in adaptation to their context."

Currently, the contexts in which graduates exercise their professions vary enormously and can call on them to use competences that have not been treated in any depth in their pre-service training, or which need to be adapted to the new context (Prats, 2010).

The specialization gained from 1st degree studies, in any subject, enables the building of a sound knowledge base; but the varying contexts in which professionals work require specific adaptations which cannot be provided by pre-service training. Experience and reflection on experience help professionals acquire this new knowledge, and in turn, to consolidate already acquired competences (Jarauta \& Medina, 2012; Pinchas, 2005). However, it is ongoing training which best promotes the assimilation and development of the competences needed for their everyday work (Imbernon, 2007).

In addition to contextual differences, constant advances in science, technology, and other areas require permanent updating in all fields of knowledge. The ways in which professionals work, relate to each other, collaborate in teams or between different branches of knowledge, careers and/or professional categories, have highly diversified forms which call for new professional competences (Bartolomé \& Grané, 2013).

All of these factors come together both separately and as a whole to make ongoing training indispensable for daily work. As early as 1970, a committee of World Health Organization experts defined ongoing training as: "training which a professional takes after completing their basic training (or any specialized training) with the goal of maintaining and/or improving their professional competence."

Arànega Susanna, associate professor, Department of Didactics and Educational Organization, University of Barcelona. Serrat Núria, tenured professor Serra Húnter, Department of Didactics and Educational Organization, University of Barcelona. 
Ongoing training also embraces new modes of working with new tools, enabling new ways of gaining access to knowledge (Fandós, 2006).

Taking into account the needs we have discussed above, ongoing training should be designed with varying contents and modes in mind, so that it may be effective and efficient in every field of knowledge; and its objectives should be set at the point where personal and collective benefits are intertwined. When any professional develops their skills, this impacts positively on their team, and thus, the whole organization is enhanced (Bolívar, 2000; Marsick, 2012).

Starting from this premise, one of the most widespread training modes in large organizations is internal training ${ }^{1}$. By this, we mean training carried out inside the organization itself, led and given by the actors making that organization.

Internal training began with the goal of addressing differing needs, on the one hand, to optimize expert knowledge (gained from experience and its constant updating) already existing within the organization; and on the other hand, to completely contextualize the contents of training, which, after years of more generalized training, is now a growing demand. There can be no one better than those who are intimately familiar with their context, and who work every day applying their knowledge, to share their expertise with colleagues.

Underpinning this idea of internal training are studies confirming that ongoing training is much more meaningful and is transferred much more easily when it is contextualized in the workplace and carried out by the very professionals making up the organization (Ruiz, 2001), "Those whose profile is that of experts within their departments."

Also, we should not forget that each and every one of the professionals working in an organization form part of it, and this should involve assuming responsibility for its growth. When the organization develops, we all develop with it, but without our individual cooperation, the organization will not achieve the goals which all of us have set and which we should reach. When an organization is able to coordinate, interweave and share knowledge and expertise, it has a much better chance of attaining success in all areas.

Individual training is necessary, but takes on more meaning when it is integrated into the organization and acts as an investment in the latter's growth (Marsick, 2012).

\section{A Brief Contextualization}

Internal training for health professionals began with very diverse objectives: to address the difficulty of articulating the myriad training courses being carried out (short and long, in all possible forms, with many different trainees, and with both highly specific and very diverse course contents); to optimize always scarce time and resources (even scarcer in times of recession); or to build motivation amongst health workers themselves.

Internal training is now a habitual practice, becoming more and more widespread in organizations; and in the case of the health services, there are many staff who have the requisite relevant knowledge which can be or needs to be transmitted to their colleagues of equal, higher or lower rank. Often, the institution needs them to share their know-how with their colleagues, so that training is one of their routine tasks, although not necessarily the most important.

Thus, we find a large number of (internal) experts who have to engage in giving training without ever having stopped to think about how they should instruct others, what their functions should be, or what training

\footnotetext{
1 The Diputació de Barcelona, the Escolad' Administració Pública, and the Institut Català de la Salut, amongst other Catalan institutions.
} 
skills they have; nor even the huge range of possible ways in which they can transmit their knowledge to their workmates/students.

This has sometimes resulted in teachers who are almost completely self-taught in terms of pedagogy, and who reproduce the academic models that they themselves have experienced as students. These models have not always been noted for their competence or for using approaches other the traditional lecture; and typically they have simply aided and abetted the accumulation of conceptual information (which can now be obtained on the internet, in articles, etc., without needing to undertake specialized training).

The innovation programme outlined below suggests that professionals currently working as trainers within their organizations, and/or those who may be experts in their field can be good internal trainers, whatever their position, sector, or line of expertise; and that they can acquire the necessary teaching competences to be good educators and to optimize their own resources as well as those of their organizations. The study was carried out from 2011 to 2015 at the Institut Català de la Salut (Catalan Health Institute), with the training unit Unió Consorci Formació (UCF) and the University of Barcelona.

\section{The Trainer Training Programme: Notes on the Innovation Programme}

The Trainer Training Programme is organized around four different sub-programmes. It is divided into these separate parts, so that each health professional can opt for the set of course contents that best fit her/his needs and expectations. Thus, we hope that each participant will be able to select the suitable level that they need to optimize their training work. The programme has a linear structure with training itineraries that allow trainees to move from one phase to another, or simply to enter directly at the phase they consider best for them.

\section{The Trainees}

The groups, consisting of 20-25 participants, are heterogeneous, drawn from different areas and departments within the organization. Since the content of each training intervention is specific, this heterogeneity helps rather than hinders the planned objectives and dynamics.

The group selection process is carried out by the organization itself, through a needs analysis and a rigorous study of each worker's skills profile. Although the training is open to all staff, often, it is necessary to select participants due to the sheer volume of demand at the enrolment stage.

\section{Structure of the Programme}

The structure of the programme is organized around the following four courses:

Course 1. Trainer training. This course is aimed at health professionals whose work involves training, who has less than three years' training experience, and who give courses and sessions irregularly. It is a foundation course for those who have no specialized pedagogical training. Its objective is to provide the basic pedagogical tools enabling them to carry out short courses and/or specific training sessions. In more detail, it aims to:

1. pedagogically equip health professionals who offer or wish to offer instruction in their organization;

2. provide the competences needed to give training in their field of expertise.

In terms of its contents, the course consists of three basic lines of work:

Tools for planning and programming instruction. Namely, how to develop a training programme, what factors should be taken into account, what phases the course should be divided into, how to organize these, etc.. 
Development of communication and methodological skills. This involves acquiring, constructing, and consolidating teaching practices based on a wide range of approaches, enabling the non-permanent trainer to provide instruction going beyond the traditional lecture-style class. Thus, we aim to teach approaches based on cooperative learning, and to provide guidelines on how to establish and maintain rapport with trainees. This part also includes a module on awareness of one's own teaching profile and the skills a trainer needs.

Learning assessment tools. Here, we work on what the assessment of learning means in ongoing training, and we offer a range of tools as alternatives to the open exam or multiple-choice test (very common in this sector).

It is a blended learning course lasting 30 hours, of which 15 will be face-to-face and 15 online.

Course 2. Perfecting teaching. This second part is aimed at health professionals who already have a more or less solid experiential grounding as trainers. Apart from instructing their workmates, they are often professionals working on masters and postgraduate course at universities, and either have to or are able to give training sessions outside their own organization.

The course has its main objective, improving and optimizing training sessions, incorporating participative methodologies more coherently, and designing and developing tailored materials to enhance teaching and to achieve better learning outcomes.

This course aims to go into greater depth in all those pedagogical factors which will enable their training work to be more than simply a transference of course contents. Among the objectives sought will be developing the capacity to analyse one's educator profile in order to create a personalized development plan. This part also provides tools for planning training interventions using varied methods and tools in order to identify which is the most suitable option for the course contents or trainees, amongst other issues. Also, in this course, we place special emphasis on assessing competences and their transference to the workplace.

The total duration of the course is 30 hours, of which 15 are face-to-face and 15 online.

Course 3. Online tutor training. This course addresses a growing need, both in health institutions and others, to programme and deliver online training systems for workers. The reasons for the emergence of this need are multiple, and we will not go into them here; but it is clear that in these institutions, there does not exist any specialized training in the specific features of the design, development and assessment of online courses. This situation has led to many face-to-face trainers taking on virtual courses without receiving suitable training in online teaching and learning.

Thus, the main objective of this course is to equip professionals with the skills and approaches they need for online training, going beyond simply technical familiarity with the platforms and interaction tools. The course has a strong pedagogical component, and this enables us to incorporate not only an instrumental section on organizing online training services, but especially, carrying out appropriate follow-up and tutoring of trainees, boosting participation among them.

This 25-hour course is also blended, with one face-to-face session and the rest online.

Course 4. Updating and specialization workshops. This course is aimed at all workers in the health sector, whether or not they have participated in the courses described above. It is made up of highly specific sessions enabling trainers to be cognizant of the latest teaching innovations relevant to their field, and to go into greater depth in a specific subject of interest for their professional development.

The design of these workshops is much more flexible, dynamic, and adaptable than the other courses, since their objective is to address the specific needs that can emerge at particular times in an organization or more generally in the medical/health field. 
Typically, these sessions will last between four and eight hours, many of these in the form of highly practical workshops.

\section{Methodology: The Cornerstone of the Programme}

One of the main strengths of this programme, embracing all the courses we offer, is the methodology used to deliver them. Thus, one of the basic premises of the project is that the methodological approach used in training is, at the same time, the contents to be learned: in order for the competences to be properly acquired, they must be understood and experienced in the training room itself; and as far as possible the trainer must also be an example of what is to be learnt and assimilated.

This undoubtedly requires active participation on the trainees' part, but above all, it involves a course programme and training method centred on:

1. Direct involvement of participants: In the programmed activities, in group discussions, in producing materials for assessment, etc.;

2. A varied approach in terms of methodology, enabling the trainee to envisage a range of different strategies that she/he can use in each training session;

3. The identification of differing teaching styles (of each of the participants) and how new learning can fit into, be assimilated and adapted to these styles;

4. The implantation of constant processes of reflection (both during and after the training received) on trainers' own practices (as trainers within the organization): reflection on their own skills and competences, on their vision of the teaching/learning process, on their role as an educator, on the incorporation of learning acquired into their day-to-day practice, etc.;

5. The putting into practice, as far as possible, of the learning acquired both in its initial context (the course), and subsequently, in their own training sessions.

Thus, the methodology we have used has been a key factor in promoting our participants' assimilation of the competences taught. We have always aimed for direct involvement of all the actors, combined with systematic reflection, to construct a form of knowledge which will ease their break from a vicious circle: That of the constant repetition of received teaching practices which, despite not necessarily coinciding with their own concept of education (or what each trainer understands by "being an educator"), provide them with security.

\section{The Organization of the Innovation Programme}

The innovation experiment was carried out from 2011-2015 in different centres of the Catalan Health Institute. To date we have delivered:

1. Eleven groups on the trainer training course;

2. Eleven groups on the perfection teaching course;

3. Eight groups on the online tutor training course.

Each course offered specific contents, while all were organized around teaching-learning activities whose objective was to experience as far as possible the approaches, tools, and processes making up the objectives and contents of the programme.

Out of the whole project, we wish to focus here on the Trainer training programme.

Table 1 below shows how the timetable of the 8 -week course was set up: 
Table 1

Work Plan

\begin{tabular}{|c|c|c|c|}
\hline Start date & Activity & Modules & Assessment \\
\hline Week 1 & $\begin{array}{l}\text { Face-to-face workshop } \\
\text { Presentation, brief explanation by } \\
\text { trainer and practical assignment for } \\
\text { trainees. }\end{array}$ & $\begin{array}{l}\text { Presentation } \\
\text { 1. Planning and programming of } \\
\text { training. } \\
\text { 2. Methodology: How to structure and } \\
\text { develop presentations. } \\
\end{array}$ & $\begin{array}{l}\text { Active participation in the } \\
\text { face-to-face session. Various } \\
\text { teaching-learning activities. }\end{array}$ \\
\hline \multirow[t]{2}{*}{ Weeks 2-3 } & $\begin{array}{l}\text { Individual task: } \\
\text { Preparation of a part of a session } \\
\text { presenting a previously agreed } \\
\text { subject, to be carried out in the } \\
\text { subsequent face-to-face session. }\end{array}$ & & Deliverable 1. Planning training. \\
\hline & $\begin{array}{l}\text { Group online task: Participation in an } \\
\text { online debate on trainers' } \\
\text { communication skills. }\end{array}$ & & $\begin{array}{l}\text { Active participation in online debate. } \\
\text { Assessment of the trainer through a } \\
\text { rubric. }\end{array}$ \\
\hline Week 4 & $\begin{array}{l}\text { Face-to-face workshop: } \\
\text { Individual presentation following } \\
\text { guidelines offered; recording and } \\
\text { analysis. }\end{array}$ & $\begin{array}{l}\text { 2. Methodology: How to structure and } \\
\text { develop presentations. }\end{array}$ & $\begin{array}{l}\text { Active participation through an oral } \\
\text { presentation. } \\
\text { Assessment of trainers using an } \\
\text { observation grid. }\end{array}$ \\
\hline Weeks 4-6 & $\begin{array}{l}\text { Online group task: } \\
\text { Animation of group forum to work on } \\
\text { the most suitable methodological } \\
\text { approaches and training materials } \\
\text { through practical cases; } \\
\text { Co-assessment of ideas put forward } \\
\text { by each group. }\end{array}$ & $\begin{array}{l}\text { 3. Methodology and approaches. } \\
\text { 4. Trainers' back-up materials. }\end{array}$ & $\begin{array}{l}\text { Active participation in online debate. } \\
\text { Deliverable } 2: \text { Co-assessment of } \\
\text { another group's task. }\end{array}$ \\
\hline Week 7 & $\begin{array}{l}\text { Face-to-face workshop: } \\
\text { Presentation and practical assignment } \\
\text { by participants. }\end{array}$ & 5. Assessment of learning. & $\begin{array}{l}\text { Active participation in the } \\
\text { face-to-face session. }\end{array}$ \\
\hline Week 8 & $\begin{array}{l}\text { Individual task: } \\
\text { Online debate analysing what trainees } \\
\text { have learnt from the course. }\end{array}$ & Transferable skills and course closure. & Active participation in online debate. \\
\hline
\end{tabular}

As Table 1 shows that there are three face-to-face sessions of five hours each, and between them the online sessions. How the sessions are organized varies according to their content, but as we mentioned in the previous section, priority is given to the interactive processes (trainer-trainees and trainees-trainees) created during the course.

\section{Analysis of Results}

Thanks to almost 45 groups (with an average of 20 people in each group) taking part in the programme over the last four years, we have obtained a range of outcomes that we would like to discuss here. For data on the implantation of the innovation, we based ourselves on information from the programme assessment. Each participant carried out a tailored assessment, evaluating various sections, from the relevance of the course contents to the methodology used, and including the assessment evidence gathered. In order to compare and contrast this information, we carried out five semi-structured interviews with the personnel in charge of setting up, running, and supervising the programme.

The results obtained may be assessed on two levels:

1. Direct and short-term, based on the direct experience of the trainers and training managers (this will be the main focus of the section below); 
2. Indirect and medium-term, based on the opinions of the trainers-in-training and their future trainees, through the implantation of their subsequent training sessions (we will discuss when we turn to future lines of work).

Firstly, and as an overall comment, we would like to remark that the pedagogical innovation programme designed and implemented has spread throughout the Catalan health services, and has been officially incorporated as a valuable training process for professionals giving training on a more or less regular basis. Progressively, new groups have enrolled, and it is now being recognized as the required qualification for becoming a trainer in health organizations. Thus, we could say that this internal training initiative has not only boosted the human and intellectual capital of the organizations involved, but has also facilitated the creation of a permanent learning culture within them.

Basing ourselves on this general overview, we would like to group our results into the following categories:

\section{Motivation to Learn and Enthusiasm}

The majority of participants (and also of managers) highlighted the need for everyone involved in training to have both motivation and enthusiasm for their educative work in their genes. Thus, trainees commented that:

A good trainer has to enjoy her/his classes, and has to try to establish straightforward and friendly contact with her/his students. I think that this was achieved in this course, both by the teacher and the students. (P-4-e8)

I could see in my classmates both enthusiasm for learning and the desire to do things properly. (G-2)

\section{Breaking with Traditional Structures and Approaches}

Another theme repeatedly emerging from participants' comments was their new vision of education. Trainees' remarks tended to show that the old "teaching = lecturing" formula is now obsolete, and that we should break with it through new methodologies and above all new ways of seeing the teaching-learning process.

The course we have done has enabled us to learn something really important: That there are attitudes, tools, and approaches for teaching. What we have to do is adapt the ones which are most suitable for us, the ones we feel most comfortable with. (P-2-e3)

This has been a different course, it is been really interactive, really motivating. (P-2-e6)

Thus, it is evident that trainer-participant interaction, and especially trainer-mediated participant-participant interaction, is a key tool in adult ongoing training. Therefore, the programme represents a qualitative change both on the "concept of training" level, and especially, on the methodological level. The programme was centred on a new teaching methodology, attempting to implant a new way of delivering training in order for participants subsequently to transfer this to their own training practices.

If, to this, we add certain "heterogeneity" in participants' previous training, experience, and motivation, the result is exponential in terms of the construction of learning.

Personally, I really liked seeing how a lot of people got "on stage" just to improve what I am doing, and also seeing the things that you really say: I present myself in this way and I have to improve this. (P-2-e3)

Talking about the atmosphere in class, I thought it was a really dynamic, participative and respectful group, led in a clever and fun way, which was able to bring out the best in all of us in very little time. (P-5-e1)

Between all of you, you have made me see other ways of getting through to students, other ways of seeing things, other activities, and other resources, with the same goal: getting across what you want to say. It has been a different course, because it has been unusual. It has been a tool for analysis and reflection and something you can benefit from when you have to lead your own training group. (P-1-e5) 


\section{Witnessing and Experiencing Processes and Methodologies in the Programme Itself}

Participating in a training course would be useless if the actual course and its practical work did not practice what they preached. Thus, the programme particularly stressed two cornerstones: planning as a foundation for developing teaching quality, and methodology as a tool for creating new participative dynamics in the construction of knowledge.

As we noted above, one of the underlying objectives of the programme was for participants to learn new teaching methodologies through their being put into practice on the course itself. This means that the methodology and tools used by the trainers can be used as an example for trainees to transfer to their own training work. The planning and methodology applied were, in themselves, the course contents.

Apart from the fact that teaching is a subject that I love (I think it could have been my second profession), I liked learning more teaching techniques and things behind the class like planning that maybe we do not give the importance that they really have. I love the idea of stimulating the student, seeing what they already know and witnessing what they are learning. (P-5-e1)

There is one thing I have learnt and understood really clearly. If we want an activity to work, it has to be really properly thought out, properly carried out, we have to be really clear about the objectives and method to use and that we want to assess. (P-1-e5)

Up to now, I have been giving training based on the knowledge of the subject that I already had and I was kind of winging it pretty well, or at least I thought so, but when you start getting new knowledge like on this course, you realise that you have got to structure your training better, you have to make it more appealing to the student and more of a challenge for me too, each time improving on the goals of the sessions that went before. (P-4-e1)

\section{Implanting Reflective Habits in Order to Promote Educators' Autonomy}

Another heading under which we could group some of the comments made is related to the boosting of reflective habits as personal tools that every trainer should include in their work. Each basic block of the course proved its worth as the course progressed, as did the trainers' decisions and actions. In turn, a series of questions were asked in each of the different feedback courses, with the aim of constructing tools which would enable participants to carry on progressing, growing, and autonomously building their own teaching style once the course was over.

This course has been different from the courses I am used to doing. I liked it because it has helped me to analyse how we do training in our centres. I think that the best thing you can take away from training in general is the ability to reflect, to think critically, and the creative capacity based on what we have learned. And, I think that was what we have seen on the course over these days. Obviously, they have only been little tastes, but enough to make us curious about how we can approach our training. (P-4-e1)

Approaches have been boosted which will later be useful as a launching pad for constant reflection on the educator's own teaching profile, both through introspection and through contributions from and comparisons with classmates. These processes have afforded a specific way of seeing how one learns and how one teaches.

Personally, this course has helped me reflect on how I approach my teaching. (P-2-e3)

Now, after this course I've Become Aware of what I should do as a teacher. (P-4-e1)

\section{Implications for Future Programmes}

As a result of the courses delivered and the lessons learnt throughout the experience, we have identified a number of implications that we would like to share here: 
1. The implantation of the programme has created new training needs among the participants. Breaking with traditional models and experiencing innovative tools and dynamics has resulted in a new way of understanding training. This has created new demands aimed at complementing and deepening various aspects of training ranging from knowledge of participative and cooperative methodologies to the use of information and communication technologys (ICTs) in education, and including the incorporation of new tools for assessing learning. To continue learning about how to develop their teaching has become a primary motivation for many of the programme's participants.

2. In our view, it is important to evaluate to what extent the learning acquired has not only been absorbed by participants, but how they transfer this learning to their day-to-training work. Thus, we would be interested to know how and to what extent they have acquired course contents and to see how they apply these as trainers. In order to do this, it would be recommendable to set up a parallel follow-up process offering new tools, elements of comparison, observations of the practices applied, etc., for those participants who wish it.

3. We are of the opinion that it is necessary to develop tools and instruments for assessing the transference of the training received. We are referring to tailored tools which would enable us to highlight the changes made and identify which of these has the greatest impact on health professionals' training practices.

4. We consider that it is necessary not only to observe how the learning acquired is transferred, but also what outcomes, in terms of impact within organizations, the programme has had. What impact on the organization has the development of staff training practices had? What levels, areas, people, etc., has it affected? What exactly is the development or improvement and how do we detect it?

These are, at the very least, the questions and implications that we consider to have emerged from the programme under discussion here. Apart from this, and from the point of view of those of us who designed and implemented the project, we can say that we are the first to have learned from it, and even, of all of its participants, those who have learnt most. Reflecting on ways of training others how to plan and teach is an inexhaustible source of pedagogical reappraisal, a never-ending cycle which enables us to continue developing our own practice as trainers. Thinking in depth about one or many of the events and processes which we set in motion in each course or session will continue to be a keynote driving us to carry out new training initiatives.

\section{References}

Alsina, J. (Ed.). (2010). Avaluació per competències a la universitat: Les competències transversals. Quaderns de docència universitària, 18. Octaedro \& Universitat de Barcelona, Barcelona.

Baarmant, L. K. J. et al. (2007). Determining the quality of competence assessment program: A self-evaluation procedure studies. Educational Evaluation, 33, 258-281.

Bartolomé, A., \& Grané, M. (2013). Interrogantes educative osdesde la sociedad del conocimiento. RevistaAloma de Psicologia, Ciències de l'educaciói de l'esport (pp. 71-83). Retrieved June 16, 2015, from http://www.revistaaloma.net

Bolívar, A. (2000). Los centros educative oscomo organizacion esquea prenden. Promesa y realidades. Madrid: La Muralla.

Fandos, M. (2006). El reto del cambioeducativo: Nuevose scenarios y modalidades de formación. Educar, 38, $243-258$.

Gibbs, G., \& Simpson, C. (2007). Condiciones parauna evaluación continuadaque favorece el aprendizaje. Barcelona: Octaedro. ICE.

Jarauta, B., \& Medina, J. L. (2012). Conocimiento profesional del profesorado y buenas prácticas de enseñanza. Estudios sobre educación, 22. Pamplona: Universidad de Navarra.

Kniventon, B. H. (1996). Student perceptions of assessment methods. Assessment \& Evaluation in Higher Education, 21(3), 229-238.

Marsick, V. (2012). Cómopuedenlas organizacion esapoyar y facilitar el aprendizaje informal en el puesto de trabajo? In J. Gairín (Ed.), Gestión del conocimiento y desarrollo organizativo. Madrid: Wolters Kluver. 
Mayo, A., \& Lank, E. (2000). Las organizacion esquea prenden: Unaguiaparaganarventajacompetitiva. Barcelona: Gestión. Pellerey, M. (2002). Evoluzione e svilup podegli approcci "per competence" nellaformazione professionale. In A. M., Ajello (Ed.), La competenza (pp. 49-78). Bologna: II Mulino.

Pinchas, T. (2005). Conocimiento profesional y personal de los profesores y de los formadores de profesores. Revista de Currículum y Formación del profesorado, 9(2), 1-10. Retrieved June 21, 2014, from http://www.ugr.es/local/recfprof/Rev9 ART3.pdf

Prats, J. (2010). Trabajar después de la universidad. La inserción laboral de los graduado suniversitarios de Cataluña. Informe CYD. Barcelona: Fundación Conocimiento y desarrollo 2001. Retrieved June 16, 2015, from http://www.ub.edu/histodida ctica

Pulgar, J. L. (2005). Evaluación del aprendizaje no formal. Recursos prácticospara el profesorado. Madrid: Narcea.

Ruiz, C. (2001). La evaluación de programas de formación de formadores en el contexto de la formación en y para la empresa (Doctoral thesis).

Starr, J. W. (1970). Student opinion methods of assessment. Education Review, 22, 243-253.

Tejada, J. (1999). Acerca de las competencias profesionales (I). Revista Herramientas, 56, 20-30.

Tejada, J. (2011). Evaluación del desarrollo professional docente basadoen competencias. In C. Marcelo (Ed.), Evaluación del desarrollo professional docente (pp. 23-47). Barcelona: DavinciContinental. 